\title{
O Adolescente: Trabalhando Perdas e a Terminalidade
}

\author{
Brunetti, Glória; Santos, Sandra; Aires, Elisa \\ Instituto de Infectologia Emílio Ribas - g.brunetti@terra.com.br
}

INTRODUÇÃO: Enfrentar as diversas perdas que sofremos, tem suas peculariedades e dificuldades. Quando se trata de adolescentes, esta situação é exarcebada, com diferentes aspectos sociais e psicológicos, tanto quando o jovem esta no processo de morrer como quando ele é quem sofre a perda de alguém. Destacaremos o acompanhamento do adolescente vivendo com HIV/aids, suas necessidades, como melhorar sua adesão ao tratamento clínico, sua sexualidade e o preconceito, muitas vezes arraigado a esta patologia. Focaremos a importância da integralidade do atendimento aos jovens e seus cuidadores e a diferença que o profissional de saúde pode fazer na travessia da infância e juventude do indivíduo, em especial, nos que sofrem perdas importantes. São caminhos que valorizam a humanização do atendimento na saúde, integralmente. OBJETIVOS: Discutir diferentes abordagens terapêuticas para adolescentes em situação de perdas e em processo de morrer; orientar profissionais de saúde no reconhecimento, acolhimento e soluções de problemas ligados às diversas perdas e em especial, à morte; ajudar profissionais de saúde e cuidadores a facilitarem a expressão dos jovens pacientes, para que eles identifiquem o que sentem, confortem-se e expressem seus sentimentos. METODOLOGIA: Estudo observacional, onde diversas ferramentas disponíveis foram usadas: EMOÇÃO: a arte como pintura e teatro, usadas como caminhos de expressão de seus medos e dúvidas, podendo dar significância a este momento e às vezes, à sua própria vida; RAZÃO: o saber científico levando à quebra de preconceitos e reforçando a importância de cada ser conheça seu corpo e suas transformações. Foi oferecido leque de opções na abordagem de adolescentes e cuidadores que enfrentam difíceis perdas como a morte, doenças neles próprios, em parentes próximos ou mesmo na não aceitação da convivência com patologias crônicas. Questionário sócio demográfico e WHO-QOL breve, estudado perfil dos adolescentes com doença crônica, HIV/AIDS e após, iniciado os diversos programas. RESULTADOS: percebido intensa melhora de humor e socialização entre os jovens, melhor interação com a equipe de saúde que inclusive passa a participar de encontros e comemorações dos jovens. a relação entre jovens, inclusive em sala de espera ambulatorial, tornou-se mais franca e serviram de apoio mútuo. a adesão clínica melhorou e se solidificou em alguns pacientes mas outros mantiveram a dificuldade na adesão medicamentosa. Melhor comunicação entre pessoas da mesma família e valorização do papel de cada um nesta dinâmica. CONCLUSÃO: mesmo em ambiente hospitalar e com baixo custo, pode ser desenvolvido programa que melhore a expressão do paciente, seus cuidadores e da equipe de profissionais de saúde, otimizando os tratamentos de saúde . com metodologia fácil e criativa pode-se otimizar espaços e situações de modo a criar ambiente favorável, para o melhor acolhimento e humanização de todos os envolvidos.

Brunetti, Glória; Santos, Sandra; Aires, Elisa. O Adolescente: Trabalhando Perdas e a Terminalidade. In: Anais do Congresso Internacional de Humanidades \& Humanização em Saúde [= Blucher Medical Proceedings, num.2, vol.1]. São Paulo: Editora Blucher, 2014. ISSN 2357-7282

DOI 10.5151/medpro-cihhs-10558 